Available online at http://journal.stkip-andi-matappa.ac.id/index.php/histogram/index

Histogram: Jurnal Pendidikan Matematika 4(2)., 2020, 565 - 580

\title{
PENGARUH MEDIA PEMBELAJARAN POWERPOINT MELALUI METODE DISCOVERY TERHADAP KEMAMPUAN PEMECAHKAN MASALAH MAHASISWA
}

Rahma Hidayati Darwis ${ }^{{ }^{*}}$

Institut Agama Islam Negeri Bone

*Corresponding Author. Email: rahma_darwis@yahoo.com

Received: 10 Agustus 2020; Revised: 15 September 2020 ; Accepted: 30 September 2020

\section{ABSTRAK}

Jenis penelitian ini adalah eksprimen semu yang bertujuan mengetahui pengaruh penerapan media pembelajaran powerpoint melalui metode penemuan terbimbing terhadap kemampuan pemecahan masalah mahasiswa. Dikatakan eksprimen semu karena tidak semua variabel yang dapat mempengaruhi kemampuan pemecahan masalah mahasiswa dapat dikontrol. Variabel yang dimanipulasi hanya variabel bebas yakni pembelajaran dengan menggunakan media pembelajaran powerpoint melalui metode penemuan terbimbing (discovery) dan variabel terikatnya adalah kemampuan pemecahan masalah mahasiswa Matakuliah Statistika Inferensial. Melalui tahapan analisis diperoleh suatu kesimpulan bahwa penggunaan media powerpoint melalui pendekatan pembelajaran discovery membuat peserta didik lebih aktif dalam proses pembelajaran sehingga memberikan stimulasi terhadap kemampuan berpikir mahasiswa. Selain itu melalui aktivitas-aktivitas yang dilakukan seperti melakukan pengamatan dan perbandingan dengan beberapa masalah yang relevan dengan materi, memperoleh bimbingan dalam membuat pola-pola sebagai embrio dari pemaknaan konsep, terlibat aktif diskusi maka diperoleh ada perubahan positif yang cukup signifikan terhadap kemampuan pemecahan masalah peserta didik Kata Kunci: Pemecahan Masalah, Media, Metode Discovery

\section{ABSTRACT}

This type of research is a pseudo-exprimen that aims to know the influence of the application of powerpoint learning media through guided discovery methods to student problem solving skills. It says pseudo-excrement because not all variables that can affect a student's problem solving skills can be controlled. Variables that are manipulated are only free variables that are learning by using powerpoint learning media through discovery methods and the bound variable is the problem solving ability of students of Inferential Statistics Courses. Through the analysis stage obtained a conclusion that the use of powerpoint media through the approach of learning discovery makes students more active in the learning process so as to provide stimulation to the thinking ability of students. In addition, through the activities carried out such as making observations and comparisons with several problems relevant to the material, obtaining guidance in making patterns as embryos of the meaning of concepts, being actively involved in discussions, there were significant positive changes to the problem-solving abilities of participants. Educate

Keywords: Problem Solving, Media, Discovery Method

How to Cite: Darwis, R, H. (2020). Pengaruh Media Pembelajaran Powerpoint Melalui Metode Discovery Terhadap Kemampuan Pemecahkan Masalah Mahasiswa. Histogram: Jurnal Pendidikan Matematika, 4(2), 565 - 580, doi: http://dx.doi.org/10.31100/histogram.v4i2.780

Permalink/DOI: http://dx.doi.org/10.31100/histogram.v4i2.780

\section{PENDAHULUAN}

Berawal dengan Undang-Undang Sisdiknas Nomor 20 Tahun 2003, yang menyatakan bahwa tujuan pembangunan nasional pada bidang pendidikan berorientasi pada peningkatan harkat dan martabat manusia, peningkatan kualitas SDM dan 


\section{Histogram: Jurnal Pendidikan Matematika, 4 (2), 2020 - 566 \\ Rahma Hidayanti Darwis ${ }^{1^{*}}$}

memperluas serta meningkatkan pemerataan dalam memperoleh kesempatan untuk menikmati pendidikan dengan penerapan prinsip demokrasi, desentralisasi, otonomi, keadilan dan menunjang tinggi hak asasi manusia. Dalam proses pencapaian dari tujuan pendidikan nasional tidaklah diperoleh dengan jalan yang mudah mengingat membangun manusia itu sangat berbeda dengan pembangunan fisik seperti jalan tol, jembatan dan lain-lain. Oleh sebab itu, agar memudahkan jalan dalam proses pencapaian, maka pemerintah berusaha melakukan penyempurnaan mengenai aturan-aturan yang memungkinkan semua pihak dapat terlibat dan medukung pencapaian tujuan pendidikan nasional.

Pendidik merupakan bagian dari ekosistem dalam dunia pendidikan yang dapat menentukan kesuksesan dalam setiap usaha pendidikan. Oleh karena itu, setiap pembicaraan mengenai revisi kurikulum, pengadaan media-media pembelajaran sebagai salah satu instrumental pendidikan sampai pada standarisasi sumber daya manusia yang dihasilkan melalui pendidikan, selalu bermuara pada pendidik. Hal ini menggambarkan atau mengindikasikan urgensi peran dari seorang pendidik dalam dunia pendidikan. Seorang pendidik memiliki tuntutan agar memiliki kompetensi pedagogic dan berbagai keterampilan yang dapat mendukung tugasnya dalam proses pembelajaran. pendidik harus memiliki kreativitas berpikir dalam melaksanakan tugasnya agar tujuan pembelajaran dapat tercapai. selain itu dibutuhkan inovasi-inovasi dalam melaksanakan tugas mengajarnya seperti penggunaan media pembelajaran yang relevan dengan materi ajar.

Kekurangan dalam proses pembelajaran saat ini, karena masih ada pendidik yang belum melakukan perubahan paradigm dalam proses pembelajarannya. Pendidik kadang tidak memperhatikan aspek-aspek lain yang dapat membantu peserta didik dalam memahami materi yang diajarkan termasuk kemampuannya dalam memecahkan masalah. Saat ini kehadiran media-media pembelajaran memberikan konstribusi yang cukup signifikan dalam proses belajar mengajar, media pembelajaran dapat dijadikan sebagai alat bantu yang efektif dalam rangka memperjelas bahan ajar yang disampaikan sehingga peserta didik akan lebih mudah memahami materi yang disampaikan. Terkadang ditemukan kesulitan meyampaikan bahan ajar kepada mahasiswa, namun kehadiran media pembelajaran dapat menyederhanakan bahan ajar tersebut. Media merupakan perwakilan dari pendidik untuk menyampaikan hal-hal yang tidak mampu disampaikan oleh pendidik melalui kata-kata atau kalimat tertentu. Bahkan bahan yang masih bersifat abstrak dapat dikonkritkan melalui penggunaan media. Dengan demikian, kehadiran 


\section{Histogram: Jurnal Pendidikan Matematika, 4 (2), 2020 - 567 \\ Rahma Hidayanti Darwis ${ }^{1^{*}}$}

media pembelajaran akan membantu peserta didik atau mahasiswa memahami atau mencerna bahan ajar, berbeda dengan proses pembelajaran tanpa penggunaan media, kadang-kadang peserta didik tidak cepat mencerna bahan yang disampaikan apalagi kalau mahasiswa tersebut memiliki gaya belajar yang memang menyukai kehadiran media pembelajaran.. Setiap pendidik diberikan otoritas untuk bertanggungjawab sendiri mengeni kegiatan pembelajaran untuk setiap mata kuliah yang diampuhnya dengan berbagai macam cara berdasarkan karakteristik peserta didik termasuk harus memperhatikan penggunaan fasilitas, peralatan, alat bantu atau media pembelajaran secara efektif. Kegiatan pembelajaran yang tidak memperhatikan penggunaan alat bantu pembelajaran atau media pendidikan secara baik bisa mempengaruhi pencapaian hasil pembelajaran belajar mahasiswa yang kurang optimal

Berdasarkan beberapa penelitian, menemukan bahwa pembelajaran yang bersifat demostrasi dalam artian materi atau informasi diperoleh melalui penjelasan pendidik tanpa menggunakan media pembelajaran sehingga hanya mengandalkan indera pendengar, maka hasil pembelajaran tersebut kurang optimal. Sebagaimana pandangan dari Dale (1994) mengestimasi bahwa, hasil pembelajaran yang diperoleh dengan menggunkan alat indera pendengaran hanya 13\% sedangkan jika dikombinasikan dengan pandangan pemerolehan hasil pembelajaran sekitar 75\%, dan melalui indra lainnya sekitar 12\%. Pandangan dari Dale ini memberikan gambaran bahwa para pendidik tidak hanya fokus pada penerimaan satu alat indera saja dalam proses pembelajaran tetapi berusaha mengaktifkan indera-indera yang lain yang tujuan agar proses pembelajaran bisa lebih optimal. Untuk itu, penggunaan media pembelajaran patut dicoba oleh pendidik yang masih mencari formulasi terbaik dalam memberikan pemahaman kepada peserta didik. Media pendidikan merupakan peralatan pendidikan yang dapat membantu pendidik dalam proses komunikasi dalam pembelajaran.

Era saat ini memberikan pengaruh yang sangat signifikan dalam perkembangan pendidikan. Zaman sekarang adalah zaman digitalisasi sehingga dirasakan bagaimana pendidikan itu ikut terpengaruh arus informasi yang serba cepat. Oleh karena itu, saatnya para pendidik untuk belajar dengan sungguh-sungguh terutama dalam penggunaan komputasi dalam merumuskan suatu media pembelajaran agar tidak tergilas dengan arus kemajuan yang saat ini sudah dirasakan. Kemajuan teknologi yang sangat cepat harus dapat diimbangi dengan kecepatan adaptasi oleh pendidik untuk terampil dalam memanfaatkan teknologi sebagai alat dalam memabantu pembelajaran seperti menggunakan teknologi seperti slide power point. 


\section{Histogram: Jurnal Pendidikan Matematika, 4 (2), 2020 - 568 \\ Rahma Hidayanti Darwis ${ }^{1^{*}}$}

Proses pembelajaran di kelas sangat dipengaruhi oleh cara atau model penyampaian materi yang dilakukan oleh pendidik. Meskipun cara guru dalam mengajar bukan satu-satunya faktor yang mempengaruhi kemampuan belajar mahasiswa, Karena ada faktor siswa, faktor lingkungan, namun kreativitas guru dalam proses pembelajaran memiliki konstribusi yang cukup besar dalam meningkatkan pemahaman peserta didiknya. Dengan demikian pendidik diharapkan mampu mengkomunikasikan suatu konsep kepada mahasiswa dengan baik agar dapat dipahami dan dikuasasi sepenuhnya oleh mahasiswa, namun tidak bisa dipungkiri dalam suatu pembelajaran dengan berbagai karakteristik peserta didiknya tidak semua dapat menguasai konsep dengan baik. Hal ini berimplikasi terhadap kemampuan penggunan konsep matematika dalam memecahkan masalah yang relatif masih rendah. Untuk itu, dibutuhkan suatu pendekatan yang terbaik berdasarkan hasil identifikasi masalah pembelajaran yang dihadapi mahasiswa agar keamampuan peserta didik dapat ditingkatkan. Salah satu hal yang perlu dipikirkan oleh pendidik adalah model pembelajaran dikombinasikan dengan penggunaan media. Beberapa penelitian telah mengungkapkan bahwa penggunaan media pembelajaran cukup berpengaruh dalam kegiatan belajar mengajar. pembelajaran akan lebih variatif dan modern apabila pendidik memiliki pengetahuan dan kemampuan mengenai teknologi komputasi.

Dari berbagai media pembelajaran yang melibatkan teknologi komputasi, media power pointlah yang saat ini sangat familiar penggunaannya, karena termasuk media yang mudah dalam penggunaannya dan bisa digunakan dalam mengkomunikasikan masalahmasalah dalam pembelajaran. media ini cocok digunakan untuk pembelajaran yang bertujuan meningkatkan kemampuan pemecahan masalah karena contoh-contoh permasalahan dapat dikomunikasikan melalui media tersebut. Namun penggunaan media harus ditopang dengan suatu metode pembelajaran yang relevan dan dalam penelitian ini, metode yang digunakan adalah metode penemuan terbimbing atau discovey mengingat yang dikembangkan adalah kemampuan pemecahan masalah peserta didi. Metode penemuan terbimbing ini memiliki salah satu kelebihan yaitu materi yang dipelajari dapat mencapai tingkat kemampuan yang tinggi dan lebih lama membekas karena mahasiswa dilibatkan dalam proses menemukannya. Kombinasi media pembelajaran powerpoint dengan metode discovery diharapkan mampu menjadi solusi bagi mahasiswa yang yang kemampuan pemecahan masalahnya masih rendah dan hanya mengekor dalam pembelajaran. berdasarkan paparan di atas peneliti tertarik melakukan suatu penelitian penelitian mengenai "pengaruh media pembelajaran powerpoint melalui metode 


\section{Histogram: Jurnal Pendidikan Matematika, 4 (2), 2020 - 569 \\ Rahma Hidayanti Darwis ${ }^{1^{*}}$}

discovery terhadap kemampuan pemecahan masalah mahasiswa di Kelompok 5 Semester VI Ekonomi Syariah IAIN Bone”. Beberapa permasalahan yang menjadi fokus penelitian adalah Apakah media powerpoint melalui metode discovery dapat mempengaruhi kemampuan pemecahan masalah mahasiswa secara signifikan?

Selanjutnya berikut ini digambarkan suatu digram yang menunjukkan kerangka berpikir dalam penelitian ini.

\begin{tabular}{|c|c|c|}
\hline Media Pembelajaran \\
Powerpoint
\end{tabular}$\quad \begin{gathered}\text { Kemampuan Memecahkan } \\
\text { Masalah }\end{gathered}$

Gambar 1. Diagram kerangka fikir

Media pembelajaran powerpoint merupakan program yang buat khusus untuk menyampaikan presentasi, dengan berbagai fitur menu yang mampu menjadikannya sebagai media komunikasi yang menarik. Melalui kombinasi dengan metode discovery diharapkan ada peruabahan yang signifikan terhadap kemampuan pemecahan masalah mahasiswa. Adapun rumusan hipotesis penelitian ini yakni: (1) $\mathrm{H}_{0}$ : Terdapat perbedaan yang signifikan kemampuan pemecahan masalah mahasiswa sebelum dan sesudah pembelajaran dengan media powerpoint melalui metode discovery; (2) $\mathrm{H}_{1}$ : Tidak ada perbedaan yang signifikan kemampuan pemecahan masalah mahasiswa sebelum dan sesudah pembelajaran dengan media powerpoint melalui metode discovery.

\section{METODE PENELITIAN}

\section{A. Jenis Penelitian}

Pendekatan yang digunakan dalam penelitian ini kuantitatif dengan jenis penelitian eksperimen semu yang bertujuan mengetahui pengaruh penerapan media pembelajaran powerpoint melalui metode disovery terhadap kemampuan pemecahan masalah mahasiswa. Penelitian ini termasuk penelitian eksperimen semu karena tidak semua variabel dapat dikontrol. Variabel yang dimanipulasi hanya variabel bebas yakni pembelajaran dengan menggunakan media pembelajaran powerpoint melalui metode penemuan terbimbing $(\mathrm{X})$ dan variabel terikatnya adalah kemampuan pemecahan masalah mahasiswa Matakuliah Statistika Inferensial (Y). berikut ini dirumuskan desain pengaruh antar variabel penelitian yang dapat dilihat pada gambar 2 berikut: 


\section{Histogram: Jurnal Pendidikan Matematika, 4 (2), 2020 - 570 \\ Rahma Hidayanti Darwis ${ }^{1^{*}}$}

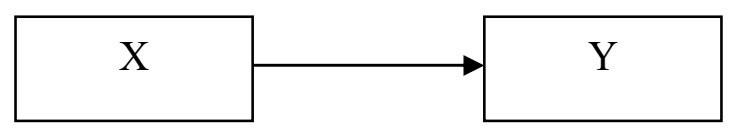

Gambar 2. Desain Penelitian

\section{B. Prosedur Penelitian}

1. Mengobservasi kondisi atau lingkungan IAIN Bone, meliputi observasi objek penelitian, pengajaran dan fasilitas yang dimiliki

2. Menentukan tingkatan atau kelas mana yang akan digunakan sebagai kelas uji coba instrumen

3. medokumentasikan nilai ujian mahasiswa untuk mengetahui kemampuan awal sebagai dalam memecahkan masalah sebagai bahan uji keseimbangan

4. Memberikan treatmen berupa proses pembelajaran melalui penggunaan media pembelajaran powerpoint melalui metode penemuan terbimbing pada kelas yang dipilih

5. Memberikan tes yang berbentu pemecahan masalah

6. Mengolah dan menganalisis data penelitian

7. Menguji hipotesis dan mengambil kesimpulan

C. Tempat dan Waktu Penelitian

Tempat penelitian ini dilaksanakan pada IAIN Bone di Kabupaten Bone. Waktu Penelitian pada Semester VI tahun ajaran 2017/2018 selama 4 bulan pada bulan Maret sampai bulan Juni 2018. Dengan Jadwal sebagai berikut

1. Bulan Maret 2018. Perlengkapan instrumen penelitian

2. Bulan April 2018. Pelaksanaan penelitian pada kelas eksperimen

3. Bulan Mei 2018. Pemberian tes kemampuan memecahkan masalah serta dilanjutkan pengolahan data statistik terhadap hasil eksperimen

4. Bulan Juni 2018, penulisan dan penyusunan laporan penelitian.

D. Populasi dan Sampel Penelitian

Penelitian ini memilih lokasi pada Instirusi Agama Islam Negeri Bone pada Fakultas Ekonomi dan Bisnis Islam. Olehnya itu yang menjadi populasi dalam penelitian ini adalah mahasiswa Ekonomi Syariah Semester VI Tahun Ajaran 2017/2018. Dalam penelitian ini, terdapat berbagai keterbatasan seperti tenaga, waktu dan dana penelitian. Dengan pertimbangan tersebut maka tidak memungkinkan bagi peneliti untuk meneliti 


\section{Histogram: Jurnal Pendidikan Matematika, 4 (2), 2020 - 571 \\ Rahma Hidayanti Darwis ${ }^{1^{*}}$}

semua siswa yang ada pada populasi, maka hanya meneliti sampel yang diambil dari populasi penelitian. Sampel yang terpilih dalam penelitian ini adalah mahasiwa kelompok 5 semester VI Ekonomi Syariah tahun ajaran 2017/2018.

Pemilihan sampel menggunakan dalam penelitian ini menggunakan teknik pengambilan sampel purposive sampling. Berdasarkan teknik sampling tersebut maka ditetapkan 29 mahasiswa sebagai satuan eksprimen, dasar penentuannya adalah kemampuan pemecahan masalah peserta didik tersebut cenderung rendah. Selain itu terdapat juga pertimbangan teknis seperti keterbatasan waktu, tenaga, dan dana sehingga tidak mengambil sampel yang besar.

\section{E. Teknik Pengumpulan Data}

1. Variabel Penelitian

Variabel bebas dalam penelitian ini yang dapat dimanipulasi adalah pembelajaran menggunakan media powerpoint melalui metode discovery, sedangkan variabel terikat yang tidak dimanipulasi adalah kemampuan pemecahan masalah.

a) Variabel bebas (Multimedia pembelajaran powerpoint melalui metode discovery)

Definisi Operasional: Multimedia dalam penelitian ini diartikan sebagai penggunaan media komputasi dalam menyajikan masalah-masalah kontekstual yang akan digunakan mahasiswa dalam menumbuhkan atau meningkatkan kemampuan pemecahan masalahnya. Dalam penelitian ini multimedia yang digunakan adalah powerpoint yang menggunakan berbagai media pembelajaran seperti LCD proyektor, aplikasi power point yang ditampilkan melalui slide, seperangkat komputer laptop untuk mengoperasikan aplikasi tersebut serta media pendukung lainnya. Metode pembelajaran yang digunakan adalah metode discoery dimana metode pembelajaran ini menempatkan mahasiswa sebagai subjek pembelajaran dan selama proses pembelajaran mengajak mahasiswa untuk berperan aktif dalam menemukan sendiri pengetahuannya.

Skala pengukuran adalah skala interval yang merupakan skala yang cocok digunakan dalam melihat kemampuan pemecahan masalah mahasiswa. Tidak ada asumsi tentang jarak dan urutan antar kategori dalam skala ini. Dalam penggolongannya adalah ketidak tumpang tindihan dan ketuntasan. Karakteristik skala pengukuran nominal adalah dapat dilakukannya klasifikasi atau kategori pengamatan.

b) Variabel terikat (Pemecahan masalah)

Definisi Operasional : Variabel terikat berupa kemampuan pemecahan masalah. Variabel ini diukur dengan test yang dilakukan setelah selesai eksperimen multimedia pembelajaran powerpoint melalui metode discovery. Kemampuan memecahkan masalah 


\section{Histogram: Jurnal Pendidikan Matematika, 4 (2), 2020 - 572 \\ Rahma Hidayanti Darwis ${ }^{{ }^{*}}$}

dalam penelitian ini adalah kemampuan mahasiswa menggunakan konsep-konsep, prosedur matematika dalam memecahkan masalah-masalah dalam kehidupan sehari-hari. Cara mengukurnya adalah dengan instrumen tes yang telah dipersiapkan sebelumnya, yaitu sejumlah soal essai sebanyak 10 butir soal. Skala pengukurannya adalah skala pengukuran interval dimana jarak dua titik pada skala sudah diketahui. Dengan indikator nilai tes kemampuan memecahkan masalah.

2. Metode Pengumpulan Data

Metode pengumpulan data yang digunakan dalam penelitian ini adalah bentuk tes. Tes digunakan untuk memperoleh informasi mengenai kemampuan pemecahan masalah mahasiswa. Metode tes ini berupa soal berbentuk pemecahan masalah sesuai dengan materi yang telah diajarkan. Tes ini memuat masalah-masalah yang berisi tentang materi yang telah diajarkan. Materi yang dijadikan sebagai soal tes adalah materi Statistika Inferensial yang berbentuk tes essai. Adapun langkah-langkah dalam penyusunan tes terdiri dari:

1) membuat kisi-kisi soal tes; 2) menyusun soal-soal tes; 3) mengadakan uji coba tes

\section{Uji Coba Instrumen}

Sebelum instrument digunakan maka terlebih dahulu dilakukan uji validitas dan realibilitas. Hal ini dilakukan bertujuan melihat apakah instrumen yang telah disusun benar-benar memenuhi kevalidan dan benar-benar reliabel. Selain itu, uji coba dipakai juga untuk melihat hal-hal lain, misalnya untuk melihat derajat kesukaran dan indeks daya pembeda. Adapun uji coba instrumen penelitian ini dilaksanakan di Prodi Ekonomi Syariah IAIN Bone pada tahun 2018. Subjek uji coba adalah seluruh mahasiswa Ekonomi syariah kelompok 4 Semster VI. Setelah uji coba selesai kemudian dilakukan analisis terhadap instrumen pengukuran kemampuan pemecahan masalah.

\section{F. Instrumen Penelitian}

Untuk memperoleh data kemampuan pemecahan masalah mahasiswa maka digunakan Instrumen berbentuk tes kemampuan pemecahan masalah. Tes kemampuan pemecahan masalah yang digunakan dalam penelitian ini adalah berbentuk tes essai terdiri dari 10 butir soal, sebelum uji cob tes yang dibuat sebanyak 15 soal namun 5 soal tidak memenuhi kriteria kevalidan. Soal tersebut terlebih dahulu dilakukan analisis validitas isi oleh validator. Setelah validasi isi terpenuhi, kemudian dilakukan uji coba tes sebelum dikenakan kepada sampel penelitian. Uji coba tes dilakukan dengan tujuan untuk mengetahui reabilitas, tingkat kesukaran, dan daya pembeda butir tes. Semua langkah ini dilakukan agar mendapatkan soal yang baik untuk diujikan, sehingga bisa menghasilkan 


\section{Histogram: Jurnal Pendidikan Matematika, 4 (2), 2020 - 573 \\ Rahma Hidayanti Darwis ${ }^{1^{*}}$}

data penelitian yang akurat. Data kemampuan pemecahan masalah ini digunakan sebagai variabel terikat dalam penelitian.

1. Analisis Instrumen Tes

a. Uji Validitas Isi

kevalidan tes sangat mempengaruhi perolehan data penelitian. Alat tes yang valid adalah tes yang dapat memberikan ukuran yang akurat. Validitas terbagi 2, namun dalam penelitian ini digunakan validitas rasional yaitu materi tes yang digunakan benar-benar bahan yang dapat mewakili keseluruhan isi hal yang diukur. Untuk tes kemampuan pemecahan masalah, supaya tes mempunyai validitas isi, harus diperhatikan hal-hal sebagai berikut:

1) Sampel yang terpilih merupakan sampel yang representatif untuk mengukur sampai berapa jauh tujuan pembelajaran tercapai ditinjau dari materi yang diajarkan atau tingkat kemampuan pemecahan masalah yang dimiliki mahasiswa.

2) Bahan materi yang diujikan harus sesuai dengan bahan materi yang diajarkan

3) Pengetahuan lain tidak diperlukan tetapi yang dibutuhkan adalah pengetahuan tentang materi yang diajarkan.

Dalam penelitian ini suatu instrumen tes dikatakan valid jika memenuhi kriteria penelaahan instrumen sebagai berikut:

1) Butir tes sesuai harus sesuai dengan kisi-kisi tes

2) Indikator tes sesuai dengan materi

3) Tingkat pemahaman siswa harus menjadi pertimbangan

4) Materi pada butir tes tidak memberikan interpretasi ganda

5) Butir tes bukan termasuk kategori soal yang terlalu mudah dan terlalu sukar

b. Uji Reliabilitas

Instrument yang baik adalah instrument yang memiliki tingkat reliabilitas tinggi. Kriteria instrument reliable adalah bila instrument tersebut memberikan hasil yang relatif sama saat dilakukan pengukuran kembali pada subjek yang berbeda pada waktu berlaikan. Pengujian reliabilias menggunakan program SPSS

Selanjutnya pemberian interpretasi terhadap koefisien reliabilitas digunakan patokan sebagai berikut: (1) $r \geq 0,70$; Reliabel; (2) $r<0,70$; tidak reliabel

2. Analisis butir instrumen tes

a. Taraf kesukaran 


\section{Histogram: Jurnal Pendidikan Matematika, 4 (2), 2020 - 574 \\ Rahma Hidayanti Darwis ${ }^{1^{*}}$}

Soal yang baik adalah soal yang memiliki indeks kesukaran yang memadu, artinya tidak terlalu mudah dan tidak terlalu sukar. Untuk mengukur tingkat kesukaran tiap butir tes, digunakan rumus sebagai berikut:

$$
P=\frac{B}{J} \ldots \ldots(1)
$$

Keterangan :

$\mathrm{P}=$ Taraf kesukaran

$\mathrm{B}=$ Jumlah responden yang menjawab benar

$\mathrm{J}=\mathrm{Jumlah}$ peserta tes

Setelah diperoleh nilai $\mathrm{P}$, kemudian diadakan interpretasi dengan mengkonsultasikan pada tabel indeks kesukaran soal seperti pada tabel berikut ini:

Tabel 1. Interpretasi Indeks Kesukaran Soal

\begin{tabular}{cc}
\hline $\mathrm{P}$ & Interpretasi Data \\
\hline $0-0,3$ & Sukar \\
$0,31-0,7$ & Sedang \\
$0,71-1$ & Mudah \\
\hline
\end{tabular}

(Sumber : Arikunto, Tahun:1998)

Dalam penelitian ini yang dipakai adalah soal dengan indeks kesukaran antara 0,31 sampai 0,70. Selain dari nilai itu, soal tidak dipakai.

b. Daya beda

Daya beda soal adalah kemampuan suatu alat ukur dalam membedakan antara mahasiswa yang mempunyai kemampuan tinggi dengan mahasiswa yang mempunyai kemampuan rendah. Daya beda suatu alat ukur merupakan proporsi penjawab item benar antara kelompok atas dengan kelompok benar. Prosedur untuk menentukan daya beda soal pada penelitian ini adalah sebagai berikut:

1) Membuat tabulasi skor butir dan skor total responden

2) Mengurutkan jenjang skor perolehan dari yang tertinggi ke yang terendah

3) Selanjutnya diambil $27 \%$ responden kelompok atas, dan $27 \%$ responden kelompok bawah

4) Menentukan indeks daya beda soal dengan menggunakan rumus sebagai berikut

$$
D B=\frac{B A-B B}{N} \ldots \ldots
$$

Keterangan :

$\mathrm{BA}=$ Jumlah benar kelompok atas

$\mathrm{BB}=$ Jumlah benar kelompok bawah 


\section{Histogram: Jurnal Pendidikan Matematika, 4 (2), 2020 - 575}

Rahma Hidayanti Darwis ${ }^{*}$

$\mathrm{N}=$ Jumlah $27 \%$ peserta tes

5) Setelah diperoleh DB, kemudian diadakan interpretasi dengan mengkonsultasikan pada Tabel Klasifikasi Daya Beda Soal berikut ini:

Tabel 2. Klasifikasi Daya Beda Soal

\begin{tabular}{cc}
\hline DB & Klasifikasi Daya Beda Soal \\
\hline$-1 \leq D B<0,2$ & Jelek \\
$0,2 \leq D B<0,3$ & Kurang Baik \\
$0,3 \leq D B<0,4$ & Cukup Baik \\
$D B \leq 0,4$ & Baik \\
\hline
\end{tabular}

6) Dalam penelitian ini yang dipakai adalah soal dengan $\mathrm{DB} \geq 0,3$.

\section{HASIL DAN PEMBAHASAN}

\section{A. Hasil Penelitian}

Instrumen tes kemampuan pemecahan masalah mahasiswa diujicobakan pada mahasiswa Ekonomi Syariah Kelompok 4 Semester VI dengan peserta tes sebanyak 27 mahasiswa. Hasil validasi diuraikan sebagai berikut:

1. Uji Validitas Isi

Jumlah butir soal soal instrumen uji coba tes kemampuan pemecahan masalah terdiri adalah 15 soal essai. Dari 15 butir soal yang diujicobakan terdapat 10 butir soal yang memenuhi tingkat validitas berdasarkan ketentuan.

2. Daya Pembeda Uji Coba Butir Soal

Dari perhitungan uji daya pembeda butir soal instrumen uji coba tes hasil beljar diperoleh :

Tabel 3. Hasil Uji Daya Pembeda untuk Butir Soal Uji Coba Tes hasil belajar

\begin{tabular}{ccccc}
\hline No & $\begin{array}{c}\text { Kriteria Daya } \\
\text { Pembeda (DP) }\end{array}$ & Butir Soal & Keputusan & $\begin{array}{c}\text { Jumlah } \\
\text { Butir }\end{array}$ \\
\hline 1 & DP $\geq 0,3$ & $1,2,5,6,8,9,11,12,14,15$ & $\begin{array}{c}\text { Butir soal dengan } \\
\text { daya pembeda yang } \\
\text { baik }\end{array}$ & 10 \\
\hline 2 & $\mathrm{DP}<0,3$ & $3,4,7,10,13$ & $\begin{array}{c}\text { Butir soal dengan } \\
\text { daya pembeda yang } \\
\text { tidak baik }\end{array}$ & 5 \\
\hline
\end{tabular}

(Sumber: Data Primer, Tahun: 2018)

Dengan memperhatikan tabel 3 maka tergambar bahwa 15 butir soal uji coba instrumen tes kemampuan pemecahan masalah, terdapat 10 butir soal yang mempunyai daya pembeda yang baik sehingga 5 butir soal ini tidak dapat digunakan sebagai instrumen penelitian tes kemampuan pemecahan masalah.

3. Tingkat Kesukaran Uji Coba Butir Soal 


\section{Histogram: Jurnal Pendidikan Matematika, 4 (2), 2020 - 576 \\ Rahma Hidayanti Darwis ${ }^{1^{*}}$}

Dari hasil perhitungan uji tigkat kesukaran butir soal diperoleh:

Tabel 4. Hasil Tingkat Kesukaran Uji Coba Butir Soal kemampuan pemecahan masalah

\begin{tabular}{ccccc}
\hline No & $\begin{array}{c}\text { Tingkat Kesukaran } \\
(\text { TK) }\end{array}$ & Butir Soal & Keputusan & $\begin{array}{c}\text { Jumlah } \\
\text { Butir }\end{array}$ \\
\hline 1 & TK $<0,3$ & $3,4,7,10,13$ & $\begin{array}{c}\text { Tingkat kesukaran } \\
\text { Sulit dan tidak baik }\end{array}$ & 4 \\
\hline 2 & $0,3 \leq \mathrm{TK}<0,7$ & $, 5,6,8,9,11,12,14,15$ & $\begin{array}{c}\text { Tingkat kesukaran } \\
\text { Sedang dan baik }\end{array}$ & 11 \\
\hline 3 & TK $>0,7$ & - & - & - \\
\hline
\end{tabular}

(Sumber: Data Primer, Tahun: 2018)

Tabel 4 memberikan informasi bahwa dari 15 butir soal uji coba instrumen tes kemampuan pemecahan masalah, terdapat 11 butir soal yang memiliki tingkat kesukaran yang baik sehingga 11 butir soal dapat digunakan sebagai instrumen penelitian kemampuan pemecahan masalah, dan terdapat 4 soal butir yang memiliki tingkat kesukaran yang tidak baik sehingga 4 butir soal ini tidak dapat digunakan sebagai instrumen penelitian kemampuan pemecahan masalah.

4. Butir Soal yang Dipakai untuk Penelitian

Berdasarkan hasil analisis tingkat kesukaran dan daya pembeda butir soal tes prestasi belajar, maka diperoleh 10 butir soal yang memenuhi syarat yaitu butir soal nomor $1,2,5,6,8,9,11,12,14$ dan 15 . Kesepuluh butir soal tersebut semuanya digunakan untuk penelitian.

\section{Reliabilitas Instrumen Tes}

Setelah dilakukan analisis daya pembeda dan tingkat kesukaran butir soal instrumen uji coba tes kemampuan pemecahan masalah, maka selanjutnya soal tersebut dilakukan perhitungan reabilitas instrumen kemampuan pemecahan masalah. Dari hasil perhitungan uji reabilitas tes hasil kemampuan pemecahab masalah dan diperoleh indeks reabilitas tes $r$ sebesar 0,84 . Karena $r=0,84$ lebih besar dari kriteria $(r=70)$, maka hail ini berarti instrumen tes kemampuan pemecahan masalah reliabel, sehingga dapat digunakan sebagai instrumen penelitian tes hasil belajar statistika inferensial.

\section{B. Pembahasan}

Selanjutnya, instrument yang sudah valid dan reliable digunakan untuk memperoleh data mengenai pengaruh media pembelajaran powerpoint melalui metode discovery terhadap kemampuan pemecahan masalah mahasiswa pada program studi ekonomi syariah IAIN Bone. Berdasarkan hasil analisis dengan mengunakan uji gain diperoleh bahwa terdapat perbedaan yang signifikan kemampuan pemecahan masalah mahasiswa sebelum penggunaan powerpoint melalui metode discovery dan kemampuan 


\section{Histogram: Jurnal Pendidikan Matematika, 4 (2), 2020 - 577 \\ Rahma Hidayanti Darwis ${ }^{1^{*}}$}

pemecahan masalah mahasiswa setelah penggunaan powerpoint melalui metode discovery. Perbedaan yang terjadi karena adanya aktivitas-aktivitas mahasiswa yang dilakukan pada penggunaan powerpoint melalui metode discovery yang sebelumnya belum pernah dilakukan dalam pembelajaran yang dilakukan oleh pendidik-pendidik yang lain. Hal ini mengindikasikan bahwa penggunaan powerpoint melalui metode discovery mempunyai pengaruh yang cukup signifikan terhadap peningkatan kemampuan pemecahan masalah mahasiswa pada mata kuliah statistika inferensial.

Penggunaan media powerpoint dengan metode discovery telah membuat mahasiswa belajar secara aktif untuk mengkonstruksi pemahamannya sendiri melalui bantuan dosen atau pendidik. Dalam kegiatan ini, dosen menstimulasi kemampuan berpikir mahasiswa yang dikemas dalam bentuk powerpoint. Adapun yang diuraikan dalam powerpoint adalah masalah-masalah dalam kehidupan nyata mahasiswa yang berkaitan dengan materi atau mata kuliah yang diajarkan. Dari masalah yang ditampilkan melalui powerpoint, mahasiswa diminta mencermati dan melakukan analisis sehingga nantinya pengetahuan mahasiswa akan terkonstruksi sendiri melalui aktivitas-aktivitas tersebut. Penggunaan power point dalam pembelajaran yang dilakukan berfungsi memudahkan dosen dalam menguraikan masalah-masalah yang berkaitan dengan materi. Jadi dosen dapat menyiapkan masalah-masalah tersebut sebelum pembelajaran dimulai sehingga juga akan mengefesienkan waktu pembelajaran. Sedangkan metode discovery adalah metode yang beorientasi pada keaktifan peserta didik atau mahasiswa. Pada metode ini, mahasiswa dituntun oleh guru untuk melakukan kegiatan-kegiatan pembelajaran seperti mengomentari, berdiskusi mengenai masalah yang diuraikan dalam powerpoint, selanjutnya menganalisis maslah tersebut sampai pada penemuan makna dari materi yang dipelajari. Melalui kegiatan tersebut, diyakini dapat meningkatkan kemampuan mahasiswa dalam menemukan makna pada suatu proses pembelajaran. Sebagaimana yang diuraikan oleh Santrock (2009) bahwa paradigma pembelajaran "pendidik menjelaskan materi secara ekspositori kemudian peserta didik mendengarkan secara pasif sudah harus ditinggalkan dan menggunakan paradigma baru yakni peserta didik mengkonstruksi makna, sedangkan pendidik bertugas menuntun atau membantu dalam menemukan makna dari materi yang dipelajari. Penelitian merupakan salah satu penelitian yang sudah membuktikan secara ilmiah melalui eksprimen bahwa hasil belajar peserta didik akan lebih baik, apabila peserta didik tersebut dipandang sebagai individu yang memiliki potensi untuk belajar dan berkembang, bukan dipandang sebagai objek yang pasif dan pendidik merasa memiliki otoritas keilmuan tertinggi dalam proses 


\section{Histogram: Jurnal Pendidikan Matematika, 4 (2), 2020 - 578 \\ Rahma Hidayanti Darwis ${ }^{1^{*}}$}

pembelajaran. Harus dipahami telah banyak penelitian maupun teori-teori belajar yang memperkuat hasil penelitian yang dilakukan.

Teori belajar yang sejalan dengan hasil penelitian ini antara lain teori belajar Brunner dalam teorinya, "free discovery learning" ia mengatakan bahwa proses belajar akan berjalan dengan baik dan kreatif jika pendidik memberikan kesempatan kepada peserta didik untuk menemukan suatu konsep, teori, aturan, atau pemahaman melalui contoh-contoh yang ia jumpai dalam kehidupannya. Menurut Bruner perkembangan kognitif seseorang dapat ditingkatkan dengan cara menyusun materi pelajaran dan menyajikannya sesuai dengan tahap perkembangan orang tersebut.

Proses pembelajaran yang dilakukan dimulai dengan mereviuw hasil kerja sebelumnya dalam rangka mengingatkan kembali kepada peserta didik materi-materi sebelumnya yang mungkin merupakan materi prasyarat. Selanjutnya dengan menggunakan media power point dosen memperlihatkan contoh-contoh atau masalahmasalah kontekstual yang berkaitan dengan materi, pada tahapan ini peserta didik diarahkan untuk melakukan pengamatan dan perbandingan yang tujuannya adalah memberikan pengalaman sebagai dasar untuk melakukan konstruksi makna. Kegiatan yang terakhrir dilakukan oleh peserta didik adalah mencari pola didalam masalah atau contoh yang diberikan oleh pendidik melalui bimbingan pendidik. Dari pola inilah peserta didik akan menemukan makna dalam proses pembelajaran yang dilakukan. melalui aktivitas belajar inilah yang menjadikan peserta didik belajar secara bermakna yang berimplikasi terhadap peningkatan hasil belajarnya.

Beberapa penelitian sebelumnya yang mendukung hasil penelitian yang dilakukan yakni Gina Rosanina dkk (2016) mengatakan bahwa dengan menerapkan model discovery learning merupakan suatu alternatif untuk meningkatan hasil belajar siswa. Begitupula yang dikemukakan oleh Nabila Yuliana (2018) dari penelitian yang dilakukan terbukti bahwa model discovery learning mampu membantu meningkatkan keaktifan siswa dalam proses pembelajaran dengan siswa menemukan informasi sendiri sehingga menunjukkan peningkatan hasil belajar siswa baik di Sekolah Dasar maupun jenjang pendidikan di atasnya. Kedua hasil penelitian di atas juga didukug oleh hasil penelitian yang dilakukan Sitti Utami Medianti, dkk (2018) mengemukakan bahwa dalam penerapaan model pembelajaran discovery peserta didik dapat lebih aktif dan melakukan pencarian sendiri sehingga hal tersebut menjadikan hasil belajar peserta didik meningkat.

Dari beberapa penulusuran penelitian-penelitian ilmiah, memberikan penguatan terhadap hasil penelitian yang dilakukan, yakni ketiga penemuan tersebut secara umum 


\section{Histogram: Jurnal Pendidikan Matematika, 4 (2), 2020 - 579 \\ Rahma Hidayanti Darwis ${ }^{1^{*}}$}

mengungkapkan bahwa ada perubahan secara signifikan hasil belajar peserta didik melalui penggunaan metode discovery. Selain itu berdasarkan beberapa penelitian yang dijadikan rujukan untuk mengembangkan penelitian ini, maka dapat dikemukakan bahwa nilai kebaruan penelitian yang dilakukan adalah terletak pada aspek yang diungkap sebagai implikasi penggunaan model atau metode pembelajaran discovery. Adapun aspek yang diungkap dalam penelitian ini adalah aspek kemampuan pemecahan masalah mahasiswa dengan menggunakan pola-pola matematika, konsep matematika, prosedur matematika dalam pembelajaran statistik ekonomi. Peneliti sengaja memfokuskan pada kemampuan pemecahan masalah, agar dapat menemukan suatu altenatif solusi untuk mengatasi rendahnya kemampuan peserta didik dalam memecahkan masalah, padahal paradigma pendidikan saat ini adalah bagaimana supaya materi yang diajarkan tidak hanya sebatas memahaminya secara teoritik tetapi juga mampu menggunakan dalam memecahkan masalah dalam kehidupan sehari-hari. Dari hasil kajian ilmiah inilah, dilahirkan suatu solusi dalam meningkatkan kemampuan pemechan masalah yakni penggunaan media powerpoint dengan pendekatan pembelajaran discovery.

\section{KESIMPULAN DAN SARAN}

Berdasarkan pembahasan yang telah diuraikan, maka dalam penelitian ini dapat ditarik kesimpulan bahwa penggunaan media powerpoint melalui pendekatan pembelajaran discovery membuat peserta didik lebih aktif dalam proses pembelajaran sehingga memberikan stimulasi terhadap kemampuan berpikir mahasiswa. Selain itu melalui aktivitas-aktivitas yang dilakukan seperti melakukan pengamatan dan perbandingan dengan beberapa masalah yang relevan dengan materi, meperoleh bimbingan dalam membuat pola-pola sebagai embrio dari pemaknaan konsep, terlibat aktif diskusi maka diperoleh ada perubahan positif yang cukup signifikan terhadap kemampuan pemecahan masalah peserta didik

Selanjutnya dalam penelitian ini juga disarankan bahwa agar proses belajar mengajar ekonomi lebih efektif dan lebih memberikan hasil yang optimal bagi peserta didik, maka disampaikan saran sebagai berikut : (1) Untuk penggunaan model pembelajaran discovery learning maka dibutuhkan persiapan yang cukup matang, sehingga pendidik harus siap dan mampu menentukan suatu topik yang benar-benardapat diterapkan melalui model pembelajaran discovery learning dalam proses belajar mengajar sehingga diperoleh hasil yang optimal; (2) Penggunaan variasi model pembelajaran akan sangat membantu peserta didik dalam memhami dan meningkatkan kemampuan pemecahan masalah. Untuk itu, pendidik hendaknya lebih sering melatih peserta didik 


\section{Histogram: Jurnal Pendidikan Matematika, 4 (2), 2020 - 580 \\ Rahma Hidayanti Darwis ${ }^{1^{*}}$}

dengan berbagai model pembelajaran, walau dalam tingkatan yang sederhana, dimana peserta didik nantinya dapat menemukan pengetahuan baru, memperoleh konsep dan keterampilan, sehingga peserta didik berhasil atau mampu memecahkan masalah-masalah yang dihadapinya; (3) Penelitian lanjutan sangat diperlukan mengingat hasil penelitian ini hanya pada program studi Ekonomi Syariah IAIN Bone

\section{DAFTAR PUSTAKA}

Al-Khalili, A. (2005). Mengembangkan kreativitas anak. Jakarta: Pustaka AL Kautsar.

Anugraheni, I. (2017). Analisa faktor-faktor yang mempengaruhi proses belajar guruguru sekolah dasar. Jurnal Manajemen Pendidikan, 4(2), 205-212.

Anugraheni, I. (2017). Penggunaan portofolio dalam perkuliahan penilaian pembelajaran. Jurnal Pendidikan Dasar Perkhasa, 3(1), 246-258.

Arikunto, S. (2008). Penelitian tindakan kelas. Jakarta: PT Bumi Aksara.

Darmadi. (2017). Pengembangan model dan metode pembelajaran dalam dinamika belajar siswa. Yogyakarta: CV Budi Utama.

Effendi, L. A. (2012). Pembelajaran matematika dengan model penemuan terbimbing untuk meningkatkan kemampuan representasi dan pemecahan masalah matematis siswa SMP. Jurnal Penelitian Pendidikan, 13 (2).

Gina Rosarina, dkk (2016). Penerapan Model Discovery Learning Untuk Meningkatkan Hasil Belajar Siswa Pada Materi Perubahan Wujud Benda. Jurnal Pena Ilmiah Vol 1 No.1

Hanifah, U., \& Wasitohadi. (2017). Perbedaan efektivitas antara penerapan model pembelajaran discovery dan inquiry ditinjau dari hasil belajar IPA siswa. Jurnal Mitra Pendidikan, 1(2), 92-104.

Indriasih, A. (2015). Pemanfaatan alat permainan edukatif ular tangga dalam penerapan pembelajaran tematik di kelas III SD. Jurnal Pendidikan, 16(2), 127-137

Kebudayaan, K. P. D. (2013). Model Pembelajaran Penemuan (discovery learning).

Muhamad, N. (2017). Pengaruh Metode Discovery learning untuk Meningkatkan Representasi Matematis dan Percaya Diri Siswa. Jurnal Pendidikan UNIGA, 10 (1), 9-22.

Nabila Yuliana (2018). Penggunaan Model Pembelajaran Discovery Learning Dalam Peningkatan Hasil Belajar Siswa Di Sekolah Dasar. Jurnal Pendidikan dan pembelajaran

Nichen Irma Cintia, Firosalia Kristin \& Indri Anugraheni, (2018). Penerapan Model Pembelajaran Discovery Learning Untuk Meningkatkan Kemampuan Berpikir Kreatif Dan Hasil Belajar Siswa

Pembelajaran Matematika. Jurnal Kependidikan: Penelitian Inovasi Pembelajaran, 41 (1).

Putrayasa, I., Syahruddin, H. \& Margunayasa, I. (2014). Pengaruh Model Pembelajaran Discovery Learning Dan Minat Belajar Terhadap Hasil Belajar IPA Siswa, II(1), hlm 1-11.

Sanjaya, Wina. (2009). Penelitian tindakan kelas. Jakarta: Kencana. Sa'ud, Udin. (2011). Inovasi pendidikan. Bandung: ALFABETA 